\title{
HIGH FREQUENCY TRANSDUCTION OF R-FACTOR ENCODED GENTAMICIN RESISTANCE BY BACTERIOPHAGE P1Cm
}

\author{
Wolfgang Piepersberg, Barbara BräU and Julian Davies* \\ Lehrstuhl für Mikrobiologie der Universität, \\ Maria-Ward-Straße 1a, D-8000 München 19, Fed. Rep. of Germany \\ *Biogen S.A., 3 Route de Troinex, 1227 Carouge, Switzerland
}

(Received for publication November 1, 1982)

\begin{abstract}
No transposition of plasmid-coded gentamicin resistance from more than fifty different R-plasmids onto a deletion derivative of bacteriophage $\lambda$ was found. In contrast, 13 out of 17 R-plasmids gave rise to the formation of high frequency transducing (hft) hybrids of phage $\mathrm{P} 1 \mathrm{Cm}$. All the hft P1Cm derivatives transduced other antibiotic resistances in addition to gentamicin resistance. The DNA sequences found to be integrated in the prophage genomes of hft phages were generally longer than $15 \mathrm{~kb}$, and ranged up to $60 \mathrm{~kb}$. In most cases analyzed the points of insertions were close to the IS1 elements resident in $\mathrm{P} 1 \mathrm{Cm}$. In part of the hybrid phages the entire R-plasmids were cointegrated. One plasmid (pWP14a) cointegrated preferentially into a $\mathrm{Bg} / \mathrm{II}$ fragment of $\mathrm{P} 1 \mathrm{Cm}$ containing an invertible structure (Cloop). Eleven out of 16 R-plasmids showed homology to IS1.
\end{abstract}

Gentamicin, a potent antibiotic against many Gram-negative bacteria causing severe infections, was introduced into therapy in 1962. Since then, in a rapidly increasing number of cases, plasmid coded gentamicin resistance involving a variety of resistance mechanisms has been reported ${ }^{1)}$. In Gramnegative bacteria these are aminoglycoside acetyl- or nucleotidyltransferases. This situation raises the question of how the genes coding for the different gentamicin modifying enzymes are disseminated in special clinical situations as well as in geographical terms. Gentamicin resistance was reported to be part of transposable DNA sequences ${ }^{2,3)}$. These all are rather large (about 9 to $14 \mathrm{~kb}$ ) stretches of DNA, and their basic structures have not been well documented. Recently, a gene coding for aminoglycoside $6^{\prime}$-acetyltransferase was claimed to be encoded on a small transposon ${ }^{4}$. The aim of this study was to obtain insight into the genetic organization of gentamicin resistance genes coding for various resistance mechanisms derived from different sources.

\section{Materials and Methods}

Organisms

Escherichia coli $\mathrm{K} 12$ strains $\mathrm{K} 802 \mathrm{NR}\left(\mathrm{F}^{-}\right.$met hsdR rif nal) and $\mathrm{HB} 101$ ( $\mathrm{F}^{-}$hsdR hsdM recA13 supE44 lacZ4 leuB6 proA2 thi-1 $\left.\left(\mathrm{B}^{-}{ }^{-}\right) \mathrm{Sm}^{\mathrm{r}}\right)$ were used as plasmid or prophage receptors in conjugation and transduction (or transformation) experiments, respectively. Bacteriophages $\mathrm{P} 1 \mathrm{Cm}$ (CmO $c 1$ ts 100), $\lambda$ (cI857 Sam7), $\lambda b b$ ( $c I 857$ b515 b518 Sam7) and $\lambda$ IS1 (cI857 N7 N53 r14) were obtained from R. REeves, R. WIRTH, laboratory stocks, and M. Howe, respectively.

Plasmids

Plasmids pRZ102 (ColE1:: Tn5) and pML2 (ColE1:: Tn903) were from W. S. ReZnikoff and M. A. Lovett, respectively. Properties of R-plasmids conferring gentamicin resistance used in this study are listed in Table 1.

Detection of Gentamicin Resistance Mechanisms

Aminoglycoside resistance mechanisms were identified by a combination of phenotypic classification and enzyme tests (acetylation and adenylylation) according to published procedure ${ }^{5,6}$. 
Table 1. R-Plasmids used in this study.

\begin{tabular}{|c|c|c|c|c|}
\hline \multirow{2}{*}{\multicolumn{2}{|c|}{$\begin{array}{c}\text { Designation } \\
\text { Strain }^{2} \text { Plasmid }\end{array}$}} & \multirow{2}{*}{$\begin{array}{c}\text { Antibiotic } \\
\text { resistances }^{\mathrm{b}}\end{array}$} & \multicolumn{2}{|c|}{ Plasmid source } \\
\hline & & & Original host (country) & Obtained from \\
\hline WP101 & pWP1 & Ap Tc Sm Km Nm Gm Tm & S. heidelberg (U.S.A.) & S. C. Nivas \\
\hline WP102 & pWP2 & Ap Tc Sm Km Nm Gm Tm Fo & S. marcescens (Spain) & J. M. ORTIZ \\
\hline WP103 & $\mathrm{pDZ1}$ & Ap Tc Sm Km Nm Gm Tm & E. aerogenes (U.S.A.) & D. ZINK \\
\hline WP105 & $\mathrm{pDZ3}$ & Ap Tc Sm Km Nm Gm Tm & E. $\operatorname{coli}$ (U.S.A.) & D. ZINK \\
\hline WP106 & pDZ4 & Ap Tc Sm Km Nm Gm Tm & S. heidelberg (U.S.A.) & D. ZINK \\
\hline WP107 & pWPa, b & $\mathrm{Gm} \mathrm{Tm} \mathrm{Hm}$ & S. typhimurium (U.S.A.) & E. V. MORSE \\
\hline WP108 & pWP8 & Ap Gm Tm & K. pneumoniae (U.S.A.) & R. O. HARE \\
\hline WP112 & pWP12a, b & Ap Gm Tm & K. pneumoniae (U.S.A.) & P. A. KRESEL \\
\hline WP114 & pWP14a, b & Ap Gm Tm & $P$. aeruginosa (U.S.A.) & P. A. KRESEL \\
\hline WP121 & pWP21 & Ap Gm Tm Ak Km Sm & C. freundii (S. Africa) & C. BLOCK \\
\hline WP156 & pWP56 & Ap Cm Tc Km Nm Sm Gm Tm & E. coli (Germany) & E. ENHUBER \\
\hline WP157 & pWP57 & $\mathrm{Cm} \mathrm{Km} \mathrm{Nm} \mathrm{Sm} \mathrm{Gm} \mathrm{Tm}$ & P. mirabilis (Germany) & E. ENHUBER \\
\hline WP164 & pWP64 & Sp Cm Tc Km Nm Sm Gm Tm & E. coli (Germany) & E. ENHUBER \\
\hline
\end{tabular}

a All strains are transconjugants of $\mathrm{K} 802 \mathrm{NR}(\mathrm{P} 1 \mathrm{Cm})$.

b The nomenclature is that proposed by Novick et al. $(1976)^{18)}, \mathrm{Fo}=$ fosfomycin, Hm=hygromycin B.

Isolation of High Frequency Transducing (hft) Bacteriophages

Preparation of lysates, transduction and lysogenization using phages $\lambda$ and P1 was carried out according to methods published ${ }^{7,8)}$. High multiplicities of infection were used (about 10 phages per bacterial cell). With $\mathrm{P} 1 \mathrm{Cm}, 10$ independent lysates from each strain were tested for giving rise to hft gentamicin resistance phages among secondary gentamicin resistant transductants. In paralell, the same procedure was carried out for kanamycin, tetracycline or fosfomycin ( $\mathrm{pWP} 2$ ) resistances for control.

Physical Analysis of DNA

The basic procedures for preparation of plasmids, for hybridization of DNA fragments, and for electron microscopic analysis of plasmid DNA are described elsewhere ${ }^{7,9,10)}$. Digestion of DNA for restriction analysis was carried out as given by suppliers of restriction endonucleases.

Chemicals

Restriction endonuclease EcoRI was from Boehringer-Mannheim, BamHI and $B g l \mathrm{II}$ from Bethesda Research Laboratories. Hygromycin B was a gift from Eli Lilly, Indianapolis.

\section{Results}

Stable Integration of Gentamicin Resistance into Phage Genomes

A generally accepted method for testing transposability of resistance genes is to investigate their ability to form stable insertions into a transferable DNA vehicle, such as plasmids or phage genomes. Therefore, we employed transduction by phages $\lambda b b$ and $\mathrm{P} 1 \mathrm{Cm}$ as a method for screening for organization of plasmid-borne gentamicin resistance in transposons.

For this purpose R-factors from a large collection of clinically isolated Gram-negative bacilli conferring resistance to gentamicin and other antibiotics were conjugated with appropriate lysogenic $E$. coli receptors and lysates of the exconjugates were tested for the ability to transduce. None of the gentamicin resistance determinants from 52 different R-plasmids could be transposed to the genome of $\lambda b b$, though this method worked well for known transposons ( $\operatorname{Tn} 5$ was used as a control). Therefore, we assume, that this type of resistance is either not transposable or the size of such elements exceeds the transducing capacity of this bacteriophage (about 7 to $8 \mathrm{~kb}^{11)}$ ). 
When $\mathrm{P} 1 \mathrm{Cm}$ was used as an alternative vector transduction of gentamicin resistance could be achieved from all 17 R-plasmid containing strains tested. Since P1 also carries out generalized transduction, secondary lysogens (transductants with complete phage $\mathrm{P} 1 \mathrm{Cm} c 1$ ts 100 phenotype) had to be screened for hft properties. From 13 out of the $17 \mathrm{R}$-plasmids hft hybrids of P1Cm could be obtained. For a given donor plasmid the ratio of formation of such phages varied from less than $5 \%$ up to $100 \%$ of secondary lysates tested.

Table 2 lists several examples of the more than $60 \mathrm{hft}$ P1Cm derivatives obtained. There was no instance found, in which gentamicin resistance was transduced alone. Also, from several R-plasmids more than a single hft phenotype was derived. From strain WP102 only hft phages carrying determinants other than gentamicin resistance genes were formed. From WP107 (Table 1) no hft derivatives were found originally. But from two structurally related plasmids, pWP7a (16 kb) and pWP7b (13.6 $\mathrm{kb}$ ) with the same phenotype as WP107, gentamicin resistance (AAC (3)-IV) and hygromycin B resistance (APH) could be transduced at high frequency after cointegration into P1Cm (data not shown).

In controls kanamycin resistance from plasmids pRZ102 (Tn5) and pML2 (Tn903) was transduced at high frequency by $\mathrm{P} 1 \mathrm{Cm}$. In most cases the entire plasmids were fused to the prophage genomes in transductants having both prophage and plasmid phenotypes (data not shown). But non-integrated plasmids were observed also. Therefore, physical interaction between prophage and plasmid DNAs was not necessary for transduction.

Table 2. Properties of different high frequency transducing (hft) derivatives of phage $\mathrm{P} 1 \mathrm{Cm}$.

\begin{tabular}{|c|c|c|c|c|c|}
\hline \multirow[b]{2}{*}{$\begin{array}{l}\text { No. of } \\
\text { isolate }\end{array}$} & \multirow{2}{*}{$\begin{array}{l}\text { Derived from } \\
\text { plasmid } \\
\left(\text { size }^{\mathrm{a}}, \mathrm{kb}\right)\end{array}$} & \multirow[b]{2}{*}{ Transduced phenotype } & \multicolumn{2}{|c|}{ DNA insert } & \multirow{2}{*}{$\begin{array}{l}\text { Gentamicin } \\
\text { modifying } \\
\text { enzyme }\end{array}$} \\
\hline & & & $\begin{array}{l}\text { Approximate } \\
\text { size }(\mathrm{kb})\end{array}$ & $\begin{array}{l}\text { Portion of } \\
\text { original } \\
\text { plasmid }^{\mathrm{b}}\end{array}$ & \\
\hline $101-12$ & pWP1 (160) & Gm Tm Km Sm Ap Cm & $19 \sim 21$ & $\mathrm{p}$ & ANT $\left(2^{\prime \prime}\right)$ \\
\hline $102-129$ & pWP2 (150) & $\mathrm{Sm} \mathrm{Ap} \mathrm{Cm} \mathrm{Fo}$ & 26.5 & $\mathrm{p}$ & \\
\hline $\begin{array}{l}103-11 \\
103-114 \\
103-123 \\
103-125\end{array}$ & pDZ1 $(160,90)$ & $\begin{array}{l}\text { Gm Tm Km Nm Sm Ap Cm } \\
\text { Gm Tm Km Nm Sm Ap } \\
\mathrm{Km} \text { Nm Cm } \\
\mathrm{Km} \text { Nm Sm Tc Cm }\end{array}$ & $\begin{array}{l}17.5 \\
\text { n.d.d } \\
\text { n.d. } \\
\text { n.d. }\end{array}$ & $\mathrm{p}$ & ANT $\left(2^{\prime \prime}\right)$ \\
\hline $\begin{array}{l}105-11 \\
105-14\end{array}$ & pDZ3 $(160,90)$ & Gm Tm Km Nm Sm Ap Cm & 17.5 & $\mathrm{p}$ & ANT $\left(2^{\prime \prime}\right)$ \\
\hline $106-119$ & pDZ4 $(150,85)$ & Gm Tm Km Sm Ap Cm & 18.5 & $\mathrm{p}$ & ANT $\left(2^{\prime \prime}\right)$ \\
\hline $112-13$ & pWP12a (21.2) & Gm Tm Ap Cm & 22 & $\mathrm{t}$ & AAC(3)-III \\
\hline $\begin{array}{c}114-4,9,11 \\
41,51 \\
71,601\end{array}$ & pWP14a (21.2) & Gm Tm Ap Cm & 22 & $\mathrm{t}$ & AAC(3)-III \\
\hline $121-41,801$ & pWP21 (60) & Gm Tm Km Nm Ak Ap Cm & 60 & $\mathrm{t}$ & $\mathrm{AAC}\left(6^{\prime}\right)-\mathrm{IV}$ \\
\hline $\begin{array}{l}156-19 \\
156-110\end{array}$ & pWP56 (90) & $\begin{array}{l}\mathrm{Gm} T \mathrm{Tm} \text { Km Nm Ap Cm } \\
\mathrm{Km} \mathrm{Nm} \mathrm{Tc} \mathrm{Cm}\end{array}$ & $\begin{array}{c}8 \\
\text { n.d. }\end{array}$ & $\mathrm{p}$ & $\operatorname{ANT}\left(2^{\prime \prime}\right)$ \\
\hline $157-11$ & pWP57 (170) & Gm Tm Km Nm Sm Cm & $21 \sim 22$ & $\mathrm{p}$ & $\operatorname{ANT}\left(2^{\prime \prime}\right)$ \\
\hline $164-11$ & pWP64 (180) & Gm Tm Km Nm Sm Ap Cm & $(1+23)^{\mathrm{e}}$ & $\mathrm{p}$ & AAC(3)-III \\
\hline
\end{tabular}

a The approximate size of large plasmids was estimated from migration in agarose gels relative to plasmids of known size (R1, R388, R478); sizes of pWP12a, pWP14a and pWP21 were determined by restriction analysis and electron micrography.

b $p=$ Part of plasmid inserted; $t=$ total plasmid cointegrated.

c The nomenclature used for $\mathrm{AAC}(3)$ and for $\mathrm{AAC}\left(6^{\prime}\right)$ enzyme classification was taken from references 1 and 5 , respectively.

d n.d.= Not determined.

- The genome structure of this phage arose probably from two different insertions and an additional deletion of P1Cm DNA. 
Physical Structure of hft P1Cm DNA

Several hft P1Cm hybrids were investigated by analysing prophage DNA from the respective lysogens by restriction mapping. Restriction endonucleases EcoRI, BamHI and BglII were used because the resulting patterns could be related to the physical map of bacteriophage $\mathrm{P} 1 \mathrm{Cm}^{12)}$. An example is given in Fig. 1 .

The following structural features of $\mathrm{hft}$ phage genomes were concluded from restriction analysis:

1. Lengths of DNA Inserts

From the lengths of additional restriction fragments, the sizes of the inserted plasmid derived sequences could be calculated (Table 2).
Fig. 1. Agarose-gel electrophoresis of restriction endonuclease cleaved prophage DNA. DNA was from 114-601 (a, d, g), P1Cm (b, e, h), and 121-801 $(c, f, i)$.

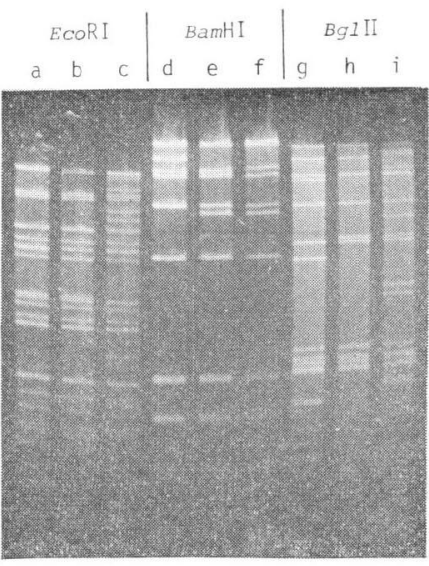

The inserted DNA sequences were more than $15 \mathrm{~kb}$ long in nearly all cases investigated (except in 156-19) and a maximum of $60 \mathrm{~kb}$ was observed. In all cases where variable phenotypes among hft phages from one and the same R-plasmid were found and in two other instances (157-11, 164-11) only part of the plasmid DNA was integrated into the phage genome. The respective donor plasmids all were large R-plasmids with lengths more than $80 \mathrm{~kb}$ (Table 2), pWP21 (about $60 \mathrm{~kb}$ ) cointegrated as a whole into $\mathrm{P} 1 \mathrm{Cm}(121-801,121-41)$, as was proven by recovery of restriction fragments from the plasmid (not shown) in the prophage DNA (Fig. 1, Table 2). This result was confirmed by measuring the length of 121-801 prophage DNA molecules from electron micrographs. DNA extracted from phage particles gave essentially the same patterns (not shown) as those from prophage DNA. This is consistent with the finding ${ }^{13)}$, that each part of a cointegrate replicon formed by fusion of phage P1 and plasmid R100 is transduced with the same probability, due to cyclic permutation.

In strains WP112 and WP114 in addition to larger plasmids (see Table 2) a relatively small plasmid of about the same size ( $21 \mathrm{~kb}, \mathrm{pWP} 12 \mathrm{a}$ and pW14a, respectively) was found, corresponding to the size of inserts observed uniformly in all hft P1Cm phages obtained from those strains. Therefore, pWP12a and pWP14a were analyzed structurally (not shown), and it could be shown that the whole plasmids were cointegrationally inserted into P1Cm. Also, both pWP12a and pWP14a, code for ampicillin resistance and gentamicin acetyltransferase of type $\mathrm{AAC}(3)-\mathrm{III}^{1)}$.

2. Location of Insertions in the Phage P1Cm Genome

In most hft prophage genomes analyzed, the sites of insertion of plasmid DNA could be unequivocally determined by analysis of the absent phage DNA restriction fragments. For instance, in 114-601 DNA the $B g l \mathrm{II}-5$, BamHI-5 and EcoRI-1 fragments ${ }^{12)}$ were lacking (Fig. 1). The EcoRI band migrating to a similar position as the P1Cm EcoRI-1 fragment is from pWP14a and occurred in all EcoRI digests of P1Cm: pWP14a cointegrates. Therefore, the smallest fragment, in which the insertion of pWP14a occurred in 114-601, was BglII-5, which is part of the BamHI-5 and EcoRI-1 fragments ${ }^{12)}$. The fusion point in cointegrate 121-801 was localized in lacking P1Cm fragments $B g l \mathrm{II}-2, B a m \mathrm{HI}-2$, and EcoRI-9, respectively (Fig. 1). Similarly, the inserts in several other hft phages were mapped (Fig. 2). 
Fig. 2. Localization of plasmid DNA insertions in several hft P1Cm hybrids.

At the top the location of $B g l I I$ cleavage sites are given ${ }^{12)}$. BglII-2 and $B g l I I-5$ fragments are redrawn in enlarged scale. In $B g l \mathrm{II}-2$ the $B a m \mathrm{HI}$ (B) and EcoRI (E) restriction sites, and the location of the tandem repeat of Tn9, flanked by IS1 elements are indicated. Fragment BglII-5 contains the C-loop, which is flanked by inverted repeats (IR $)^{14)}$. The smallest fragments in which inserts could be localized (see text), are indicated by the lines below.

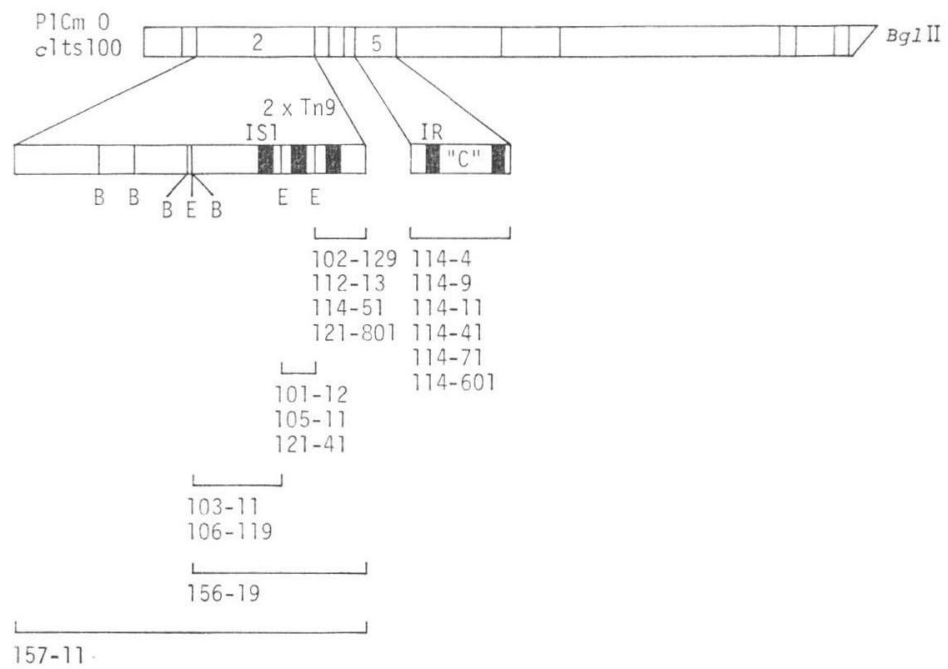

3. Physical Similarities between R Determinants Integrated in $\mathrm{P} 1 \mathrm{Cm}$

Insertions in 101-11, 103-11, 105-11, and 106-119 are all of similar size (Table 2), and contain common BglII $(0.85 \mathrm{~kb})$, BamHI $(3.1$ and $4.2 \mathrm{~kb})$, and EcoRI $(3.5 \mathrm{~kb})$ fragments. All R-plasmids, from which these are derived, are from pathogenic enterobacteriaceae isolated in turkey farms throughout the U.S.A., have the same resistance patterns, and code for aminoglycoside nucleotidyltransferase, $\operatorname{ANT}\left(2^{\prime \prime}\right)$ (Tables 1 and 2). It is concluded therefore that R-plasmids in strains WP101, 103, 105, 106 all originate from a common source.

None of the hft P1Cm derivatives hybridized to a probe made from the AAC(3)-I gene cloned from JR8 ${ }^{15}$ (data not shown), indicating that (genetically) large divergence exists between aminoglycoside acetyltransferases $(3)^{1)}$.

\section{Occurrence of IS1 Elements on R-Factors Studied}

IS1-specific hybridization was detectable in 11 out of 16 gentamicin R-plasmids tested including pWP1, 21, 56, 57, 64, pDZ3 and five other, not further characterized plasmids (data not shown). This large proportion indicates, that IS1 is a natural constituent of many R-plasmids, and that its presence may account at least in part for the recombination events leading to the structures of the hybrid phages described. No homology between IS1 and plasmids pWP2, 7a, 7b, 12a, 14a was detected (data not shown).

\section{Discussion}

One possible route to the evolution of multiple antibiotic resistance conferring plasmids in nature, is the following: A limited number of self-transmissible plasmids, of IS elements, and a low-concentration pool of resistance genes seem to be sufficient to make a given bacterial population adaptable to toxic environments in a short period of time. The plasmids serve as collectors and transporters on 
which several r-determinants can be accumulated, promoted by the recombinational activity of IS elements. Secondly, IS elements again could be involved in the transfer of these genes to other plasmids. Cointegrate formation of two different plasmid replicons seems to be the initial step in this process and various products can be formed by several types of secondary reactions ${ }^{16)}$. In a third phase of development composite resistance transposons are built up from IS modules making the respective genes movable onto most replicons ${ }^{18)}$. Though it is not known, for the transposons described so far whether they existed before the respective antibiotics were widely used it seems very likely that new ones could evolve and disseminate under the selective pressure of extensive and long term use of chemotherapeuticals.

If this view is correct and used to analyse our experimental data, the current situation with respect to gentamicin resistance in bacteria seems to be characterized as follows: Several genes for gentamicin modifying enzymes ${ }^{1)}$ have been mobilized from originally, rarely-occurring sites during the last two decades. Since gentamicin was introduced into therapy relatively recently, the gentamicin resistance genes were incorporated into preexisting R-plasmids, conferring various other antibiotic resistances. Therefore, the gentamicin resistance genes became part of larger sets of determinants, and, where transposable, of more complicated structures comparable to Tn2671 ${ }^{17)}$. This could be the case for plasmids of the type of pWP1, from which various different hft P1Cm derivatives were obtained (Table 2).

It can be predicted, that small composite gentamicin resistance transposons, comparable to $\operatorname{Tn} 5$ or Tn903 that carry resistance to the "older" aminoglycoside kanamycin, are likely to be found more frequently in the future. The report on $\mathrm{Tn} 2401^{4)}$ carrying an $\mathrm{AAC}\left(6^{\prime}\right)$ activity may be the first indication of recent development and spreading of such elements. In other cases gentamicin resistance genes have been found in the vicinity of IS elements without forming transposons (BRÄU and PIEPERSBERG, unpublished data). These elements are very active in promoting cointegration of the respective plasmids into other replicons.

Many details remain still obscure: What is the source of gentamicin resistance genes? What is their function in nature? Do resistance genes need to have certain structural features to become integrated into stable transposons?

\section{Acknowledgments}

We thank A. Böck for helpful discussions and for support, and M. Geier for typing the manuscript. We are grateful to many colleagues for sending strains. This work was supported by grants from the NIH (to J.D.) and the Deutsche Forschungsgemeinschaft (to W.P.).

\section{References}

1) Davies, J. \& D. J. Smith: Plasmid determined resistance to antimicrobial agents. Ann. Rev. Microbiol. 32: $469 \sim 518,1978$

2) Rubens, C. E.; W. F. MCNeill \& E. Farrar: Transposable plasmid deoxyribonucleic acid sequence in Pseudomonas aeruginosa which mediates resistance to gentamicin and four other antimicrobial agents. J. Bacteriol. 139: 877 882, 1979

3) Datta, N.; M. Nugent \& H. Richards: Transposons encoding trimethoprim or gentamicin resistance in medically important bacteria. Cold Spring Harbor Symp. Quant. Biol. 45: 45 51, 1981

4) Schmidt, F.; J. Kratz \& B. Wiedemann: Identification of Tn2401, a transposon encoding multiresistance to aminoglycosides. In. Bacterial Resistance to Aminoglycoside Antibiotics. Proceedings of the Symposium by the Paul-Ehrlich Society for Chemotherapy and the British Society for Antimicrobial Chemotherapy. B. Wiedemann \& D. S. Reeves, Eds., pp. 68 75. Bad Honnef, Germany, April 1981

5) Miller, G. H.; F. J. Sabatelli, R. S. Hare \& J. A. Waitz: Survey of aminoglycoside resistance patterns. Develop. Indus. Microbiol. 21: $91 \sim 104,1980$

6) Davies, J.: Aminoglycoside-aminocylitol antibiotics and their modifying enzymes. In Antibiotics in Laboratory Medicine. V. LoRIAN, Ed., pp. 474 489. Williams and Wilkins, Baltimore, London, 1980

7) DAvis, R. W.; D. Botstein \& J. R. Roth: Advanced bacterial genetics. A Manual for Genetic Engineering. Cold Spring Harbor Laboratory. Cold Spring Harbor, New York, 1980

8) Heilmann, H.; A. Pühler, H.-J. Burkhardt \& J. N. Reeve: Transposon mutagenesis of the gene encoding the bacteriophage P1 restriction endonuclease. Colinearity of the gene and the gene product. J. Mol. 
Biol. 144: 387 396, 1980

9) Southern, E. M.: Detection of specific sequences among DNA fragments separated by gel electrophoresis. J. Mol. Biol. 98: 503 517, 1975

10) Sharp, P. A.; M.-T. Hsu, E. Ohtsubo \& N. Davidson: Electron microscope heteroduplex studies of sequence relations among plasmids of Escherichia coli. J. Mol. Biol. 71: 471 497, 1972

11) Feiss, M.; R. A. Fisher, M. A. Crayton \& C. Egner: Packaging of the bacteriophage $\lambda$ chromosome: Effect of chromosome length. Virology 77: 281 293, 1977

12) ImA, S. \& W. Arber: Multiple physical differences in the genome structure of functionally related bacteriophages P1 and P7. Mol. Gen. Genet. 173: 249 261, 1979

13) IIDA, S.: A cointegrate of the bacteriophage P1 genome and the conjugative R plasmid R100. Plasmid 3: 278 290, 1980

14) YUn, T. \& D. VAPNeK: Electron microscopic analysis of bacteriophages P1, P1Cm and P7: Determination of genome sizes, sequence homology, and location of antibiotic resistance determinants. Virology 77: 376 385, 1977

15) Kagan, S. A.: Aminocyclitol acetyltransferase(3)-I: Structure and function. Thesis (PhD), University of Wisconsin, Madison, 1981

16) KleCKner, N.: Transposable elements in prokaryotes. Ann. Rev. Genet. 15: 341 404, 1981

17) IIDA, S.; C. HÄnNi, C. Echarti \& W. Arber: Is the IS1-flanked r-determinant of R-plasmid NR1 a transposon? J. Gen. Mikrobiol. 126: 413 425, 1981 